\title{
"The impact of decentralization on the financial support of regional development"
}

\begin{tabular}{|c|c|}
\hline AUTHORS & $\begin{array}{l}\text { Oksana Tulai (D https://orcid.org/0000-0002-5588-7046 } \\
\mathbb{R} \text { https://publons.com/researcher/2118085/oksana-tulai/ } \\
\text { Yuriy Petrushenko (D https://orcid.org/0000-0001-9902-7577 } \\
\text { R http://www.researcherid.com/rid/C-1072-2018 } \\
\text { Jozef Glova D https://orcid.org/0000-0001-5972-7771 } \\
\text { R https://publons.com/researcher/3130398/jozef-glova/ } \\
\text { Iryna Sydor (D https://orcid.org/0000-0002-4410-7083 } \\
\text { Oksana Ponomarenko (D) https://orcid.org/0000-0003-2406-5637 }\end{array}$ \\
\hline ARTICLE INFO & $\begin{array}{l}\text { Oksana Tulai, Yuriy Petrushenko, Jozef Glova, Iryna Sydor and Oksana } \\
\text { Ponomarenko (2019). The impact of decentralization on the financial support of } \\
\text { regional development. Investment Management and Financial Innovations, 16(4), } \\
\text { 1-15. doi:10.21511/imfi.16(4).2019.01 }\end{array}$ \\
\hline DOI & http://dx.doi.org/10.21511/imfi.16(4).2019.01 \\
\hline RELEASED ON & Wednesday, 16 October 2019 \\
\hline RECEIVED ON & Thursday, 05 September 2019 \\
\hline ACCEPTED ON & Friday, 27 September 2019 \\
\hline LICENSE & $\begin{array}{l}(c) \text { EY } \\
\text { This work is licensed under a Creative Commons Attribution } 4.0 \text { International } \\
\text { License }\end{array}$ \\
\hline JOURNAL & "Investment Management and Financial Innovations" \\
\hline ISSN PRINT & $1810-4967$ \\
\hline ISSN ONLINE & $1812-9358$ \\
\hline PUBLISHER & LLC "Consulting Publishing Company "Business Perspectives" \\
\hline FOUNDER & LLC “Consulting Publishing Company "Business Perspectives" \\
\hline
\end{tabular}

NUMBER OF REFERENCES

24

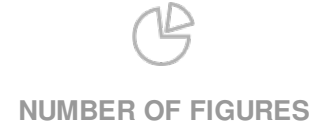

6

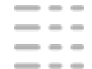

NUMBER OF TABLES

11

C The author(s) 2023. This publication is an open access article. 


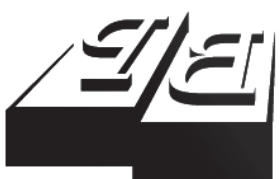

BUSINESS PERSPECTIVES

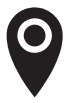

LLC "CPC "Business Perspectives"

Hryhorii Skovoroda lane, 10,

Sumy, 40022, Ukraine

www.businessperspectives.org

Received on: $5^{\text {th }}$ of September, 2019 Accepted on: $27^{\text {th }}$ of September, 2019

C Oksana Tulai, Yuriy Petrushenko, Jozef Glova, Iryna Sydor, Oksana Ponomarenko, 2019

Oksana Tulai, Doctor of Economics, Professor of S.I. Yuriy Department of Finance, Ternopil National Economic University, Ukraine.

Yuriy Petrushenko, Doctor of Economics, Professor, Head of the Department of International Economic Relations, Sumy State University, Ukraine.

Jozef Glova, Associate Professor, Doctor in Finance, Head of Department of Banking and Investment, Faculty of Economics, Technical University Kosice, Slovak Republic.

Iryna Sydor, Ph.D. in Economics, Associate Professor of S.I. Yuriy Department of Finance, Ternopil National Economic University, Ukraine.

Oksana Ponomarenko, Ph.D. Student, specialist of Department of International Economic Relations, Sumy State University, Ukraine.

\section{(ㄷ) (i)}

This is an Open Access article, distributed under the terms of the Creative Commons Attribution 4.0 International license, which permits unrestricted re-use, distribution, and reproduction in any medium, provided the original work is properly cited.
Oksana Tulai (Ukraine), Yuriy Petrushenko (Ukraine), Jozef Glova (Slovakia), Iryna Sydor (Ukraine), Oksana Ponomarenko (Ukraine)

THE IMPACT

OF DECENTRALIZATION
ON THE FINANCIAL SUPPORT
OF REGIONAL DEVELOPMENT

\begin{abstract}
Nowadays in Ukrainian realities decentralization, as a process of expanding and strengthening the rights and powers of administrative-territorial units, contributes to the development of financial innovations, the accessibility of public goods, and improvements in the quality of life of the population.

The aim of the article goal is developing the recommendations for improving the financial support of the regions by introducing new tools of influence of communities and local self-governments on the economic growth of territories.

Using the methods of factor analysis, regression analysis, and significant components, the article determines the impact of regional economic development on the revenues of local budgets. The empirical findings show the close correlation between budgetary decentralization and industrial capabilities of the regions. A cluster analysis was carried out to identify the asymmetries of regional development in terms of financial capacity. It enabled to distinguish homogeneous groups of areas according to the indicators of their economic development. On this basis the authors substantiated the necessity of entrepreneurial activity stimulating, increasing the number of companies, and promoting a continuous flow of goods (works, services) from the producer to the consumer in different regions of Ukraine.
\end{abstract}

Keywords

JEL Classification G28, E62, H72

\section{INTRODUCTION}

The increasing differentiation in the efficiency of functioning of the economy of Ukraine's regions and the introduction of decentralization mechanisms in the sphere of relations between central and local authorities necessitated a change in the approaches to financial support of the regions' development. Decentralization, as a process of expanding and strengthening the rights and powers of administrativeterritorial units, is aimed at improving the standards and quality of life of the population. It should be noted that decentralization of governance is carried out solely on the initiative and under the control of public authorities. At the same time, it is impossible to carry out decentralization if local governments are not ready to take responsibility. In the developed countries decentralization is an effective tool for government reorganization to provide the most efficient delivery of public services. Under the current conditions budgetary decentralization of power, as a component of state regional development policy, is one of the defining reforms in Ukraine. It has created the foundation for the entrenchment of institutional transformations and for improving the quality of life of residents. It is also of great importance for the 
continuation of sectoral reforms. The creation of a new system of distribution of powers between the central and local authorities in Ukraine has led to the formation of a new system of relations between different branches of power and a new balance of checks and balances. The peculiarities of the financial potential of regions, which reflect the level of economic development of certain territories, are particularly important. After all, the financial support for the development of Ukraine's regions depends on the ability of economic entities to form and increase their financial potential, the efficiency of management of financial resources and the factors of social, economic, environmental and political nature caused by destabilization processes in the country. Therefore, under the current conditions it is important to identify reserves for the formation and growth of the financial potential of regions and to increase the efficiency of use of the available financial resources. The issues of financial support for the development of Ukraine's regions in the context of budgetary decentralization need theoretical and practical conceptualization.

\section{LITERATURE REVIEW}

A significant contribution to the study of the theories of fiscal regulation was made by Musgrave (1957), R. Musgrave and P. Musgrave (1989). They emphasize that the main economic functions of the government should aim at ensuring macroeconomic stability, the efficiency of public finances, and guarantee equal distribution of revenues. The conclusions of Oates $(1994,1972)$ on the appropriateness of decentralization are based on the justification of the effects of asymmetric information: the central government cannot have comprehensive information about the preferences of residents of individual regions in terms of budget services and the level of the costs of their support. This requires decentralized budgeting for certain services. The researcher argues that when certain public goods are provided in a decentralized manner, there is an increase in the efficiency of their support and, therefore, the capacity benefits of decentralization can be quite high. Tiebout (1956) formulated a hypothesis, which explains that in the context of significant numbers of territorial units and the free movement of the population, budgetary decentralization will create conditions for achieving comparatively higher efficiency of providing public benefits at the level of local self-government. Each person has an opportunity to choose the optimal set of local public goods and their prices (local taxes). Vedel (1973) emphasizes in his writings that decentralization consists in the transfer of powers not to civil servants and bodies representing the central government, but to other institutions, which are not hierarchically subordinated to the latter, mainly elected by the population.
Barro (1990) created an endogenous model of economic growth, which assumes that public goods determined by the level of federal spending and included in the production function determine the level of economic growth.

The study of the mechanism and organization of financial support for the activities of local authorities and realization of their own and delegated powers is done in the works of Gibson et al. (1991), Faguet (1997). In particular, Gibson, Ivancevich, and Donelli (1991) focus their attention on the mechanism of transfer of power regarding the making of financial decisions to the lowest possible level of authorities within a single organizational structure. Faguet (1997) substantiates the need of decentralization for more equitable economic growth and income redistribution emphasizing that local self-governments need to implement their projects and that they need their tax base and the ability to transparently protect their share in central taxes and a certain autonomy in the use of the collected fees.

In general, one should note that the EU countries are searching for a useful model of public administration. This process yields several models that have higher or lower levels of decentralization (World Bank, 2002). According to Arikan (2004), Fisman and Gatti (2002), decentralization reforms can contribute to reduced corruption, while an economic system with lower corruption levels can lead to dynamic economic growth. Therefore, the decentralization of financial resources will add to the satisfaction of the interests of residents of territorial communities and regions in general. During decentralization, there will be competi- 
tion between local authorities to attract businesses by creating transparent rules of the game in the regions.

The approaches to the financial support of the development of individual regions and communities are analyzed by the World Bank (2005). Kendall (2012) examined the relationship between financial resources and the rates of local development. Affleck and Mellor (2006) analyzed the peculiarities of monetary policymaking at the local level.

In recent years, the Ukrainian researchers Andrushchenko (2013) and Lunina (2014) have been actively involved in the study of decentralization processes and their financial support in Ukraine.

An approach to assessing the impact of budgetary decentralization on the country's economic growth was proposed in the works of Pasichnyi (2017). The impact of participatory financing on the development of local communities was analyzed in the work of Petrushenko et al. (2017). The effect of the peculiar features of territorial and regional development on the formation of municipal budgets was analyzed by Kuzkin (2018). There are also scientific publications that examine the impact of fiscal decentralization on the sustainable development of regions and communities (Chygryn et al., 2018; Tulai, 2016; Kozarezenko et al., 2018).

However, despite the existing regulatory framework and professional developments on the issues of decentralization and its financial support, a large number of issues remains under-researched.

The purpose of the article is to identify the ways for improving the financial support of regions with a view to the deepening budgetary decentralization in the country and conducting the administrative-territorial reform, as well as clarifying the impact of economic development indicators of the region on the formation of its financial capacity - the main component for improving the standard of living and quality of life of its residents.

Results of the research. People's needs change under the influence of scientific and technological progress, globalization, and the development of foreign economic relations. At the same time, there is an increase in the requirements of the population regarding the quality of goods and services. Given the above, the centralized support of public goods is ineffective.

Local authorities, which are closer to the residents of the respective administrative and territorial units and possess the necessary information about the needs of residents and economic situation in the region, perform their tasks and functions more effectively than under a centralized system of management. In general, there are several reasons for the need for decentralization:

1) political changes that allowed local communities to defend their positions;

2) technological changes and global integration, which have significantly changed the vision of processes of centralized management and local self-government;

3) problems of the centralized system of management and the need for the participation of local self-government bodies in political and economic life.

Budgetary decentralization is a way of organizing the relations of the fiscal system among the budgets of different levels through the transfer of powers with the appropriate financial resources from the center to the regional and local levels of self-government. The reallocation of functions accompanies it among different levels of authorities for the benefit of regional and local governments. It corresponds to the "golden rule" of public finances: spending should not be quantitative, but efficient and closer to taxpayers and consumers of publicly funded services (Blankart, 2000).

We share the opinion of Oates $(1972,1994)$ that in the process of budgetary decentralization, it is necessary to create conditions for:

- support of public goods under the needs and preferences of the local population;

- increasing the responsibility of local authorities for the execution of functions assigned to them, and therefore for the efficiency of local budget expenditures; 
Source: Compiled and summarized by the authors.

\begin{tabular}{|c|c|}
\hline \multirow{3}{*}{ 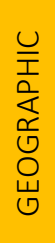 } & Activation of economic development of non-urban areas \\
\hline & Stimulation of business development in rural areas \\
\hline & Stimulation of investment attractiveness of the rural regions \\
\hline \multirow{3}{*}{$\begin{array}{l}\overrightarrow{\mathbb{S}} \\
\stackrel{\Xi}{E} \\
\stackrel{\overrightarrow{0}}{0}\end{array}$} & Distribution of political power and support of regional representation in the parliament \\
\hline & Direct election of representatives of local authorities \\
\hline & Encouraging citizens' participation in local self-government \\
\hline \multirow{3}{*}{ 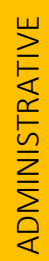 } & Broader delegation of powers to the local authorities \\
\hline & Ensuring effective management by reducing the multi-level process of decisions' execution \\
\hline & Increase in the efficiency of public administration bodies \\
\hline \multirow{3}{*}{ 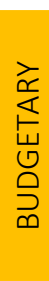 } & Ensuring the relationship between the management system and the public \\
\hline & Providing local governments with relevant taxing authority and budgeting \\
\hline & $\begin{array}{c}\text { Adequate level of autonomy for local authorities enabling them } \\
\text { to make independent decisions }\end{array}$ \\
\hline
\end{tabular}

\section{Figure 1. Types of decentralization}

- growth of spending of local budgets in proportion to the growth of revenues and economic development of the corresponding territory.

At the same time, one should note that the process of decentralization can have both positive and negative consequences (Table 1).

In our opinion, to ensure sustainable development, the interaction of different levels of authorities should meet the following conditions:
- the existence of clear separation of powers between the levels of state power;

- local authorities should have sufficient autonomy to pursue budgetary policies within their powers and territories;

- local authorities are subject to budget constraints.

This means that in the case of an increase in local budget revenues, there are no transfers to high-

Table 1. Advantages and disadvantages of decentralization

Source: Compiled and summarized by the authors.

\begin{tabular}{l|l}
\hline \multicolumn{1}{c|}{ Advantages of decentralization } & \multicolumn{1}{c}{ Disadvantages of decentralization } \\
\hline Positive impact on macroeconomic indicators & $\begin{array}{l}\text { Complexity of the process of management of the macroeconomic } \\
\text { situation }\end{array}$ \\
$\begin{array}{l}\text { Ability to meet the needs of the population with quality } \\
\text { services on the local level }\end{array}$ & $\begin{array}{l}\text { Disproportions and unevenness of socio-economic development of } \\
\text { administrative-territorial units }\end{array}$ \\
\hline Formation of competitive local self-government bodies & $\begin{array}{l}\text { The likelihood that the performance of delegated state functions will be } \\
\text { less coordinated both vertically and horizontally }\end{array}$ \\
\hline Stimulating the growth of civil society & $\begin{array}{l}\text { Low level of awareness of civil society can provoke "unfair" use of power } \\
\text { Development of the regional economy }\end{array}$ \\
\hline
\end{tabular}


er-level budgets, while higher-level budgets do not offset the deterioration of the financial and economic situation. At the same time, if a decrease in revenues or an increase in local budget expenditures is the result of a decision taken by a higher level of authorities, the compensation for these funds is mandatory.

The consideration of the problems of development of inter-budgetary relations should begin with an analysis of two concepts: the concept of financial centralization and the concept of fiscal decentralization.

The concept of financial centralization implies an explicit subordination of local governments to higher levels of authorities and their vertical subordination based on the relevant legal acts. This concept is based on the idea of accumulation of the basic taxes by the national government (Barro, 1990). This model of financial management is acceptable for countries with low levels of economic diversification, as they suffer from fluctuations in the global economy, external debt, chronic inflation, etc. An essential aspect of this model's application is the ability of central governments (compared to local governments) to more professionally administer the taxes and more effectively allocate the budgetary resources.

From the point of view of production of public goods, the benefits of the centralized model in- clude cost reduction due to the increase in volumes (the higher the number of consumers, the lower the cost per consumer) and standardization of the quality of public goods (centralization makes it easier to introduce uniform quality standards for public goods).

The search for new approaches to the organization of state management led to the rejection of the traditional type of administrative reality and actualization of the processes of self-organization and self-government of social systems, as well as to an increase in social efficiency of public administration. The concept of budgetary decentralization implies an extension of financial powers and the financial responsibilities of local self-government authorities.

Therefore, decentralized management is a much more complicated process than the centralized one. This is related to the fact that multilevel structures are formed in the process of decentralization. The public understands the model of decentralized financial management in the context of the relationship between the paid taxes and the received public goods.

The satisfaction of the needs of the population living on a particular territory depends directly on the revenues of the local budget.

As shown in Figure 2, transfers account for the largest share $(59.08 \%)$ in the structure of local

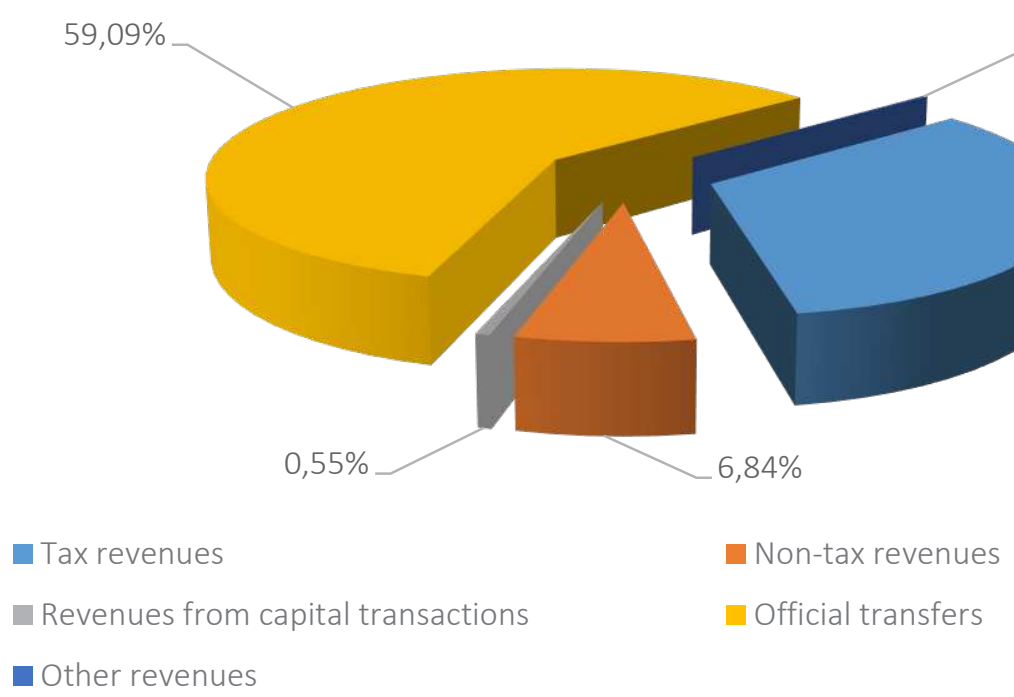

Figure 2. The structure of revenues of local budgets in Ukraine in 2015 


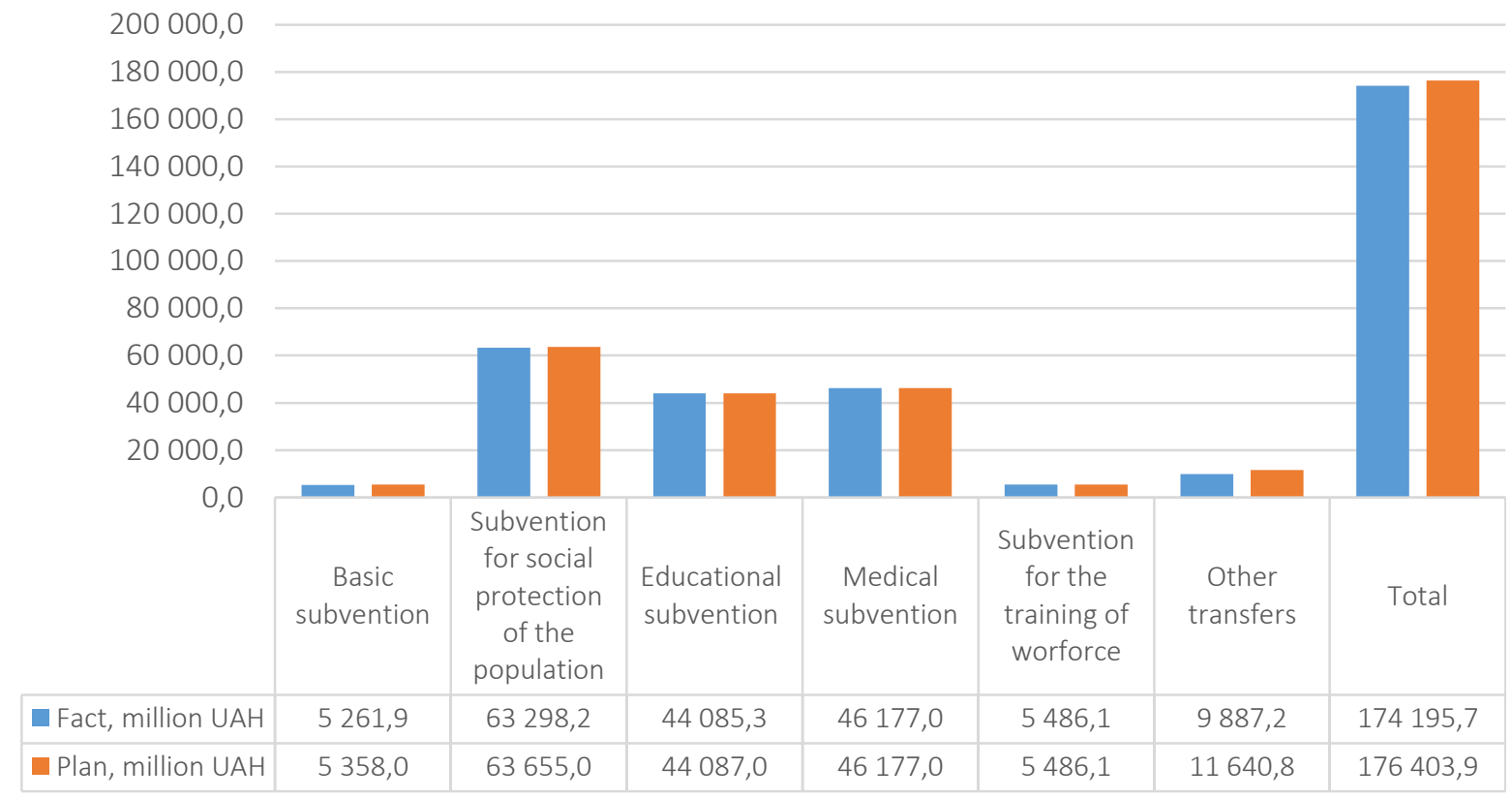

Figure 3. The structure of inter-budgetary transfers in 2015

budget revenues. According to the Budget Code of Ukraine, in 2015, local budgets obtained basic subsidies and subventions for social security of the population, education, medicine, training of employees, and other transfers. Most of them aim at the social security of the population, health care, and education (Figure 3).

Seventeen regions of Ukraine received a significant amount of transfers (over $60 \%$ in the structure of local budget revenues). The share of transfers in local budget revenues of seven regions (Dnipropetrovsk, Donetsk, Zaporizhzhia, Kyiv, Odesa, Poltava, Kharkiv regions) ranged from $49.94 \%$ to $57.96 \%$; the share of transfers in the budget revenues of Kyiv was $29.94 \%$ (Figure 4).
Tax revenues comprise only $33.36 \%$ of local budget revenues (Figure 2), which indicates the need to develop and implement the mechanisms for improving the system of financial support for self-sufficiency and development of territorial communities. The collaboration between communities, local authorities, and businesses in the respective territories needs to be stepped up.

In our opinion, budget decentralization closely correlates with the economic capabilities of the regions. Therefore, we propose to create a system of indicators that makes it possible to take into account the peculiarities of development of the regional economy and to show their impact on local budget revenues (without considering inter-budgetary transfers).

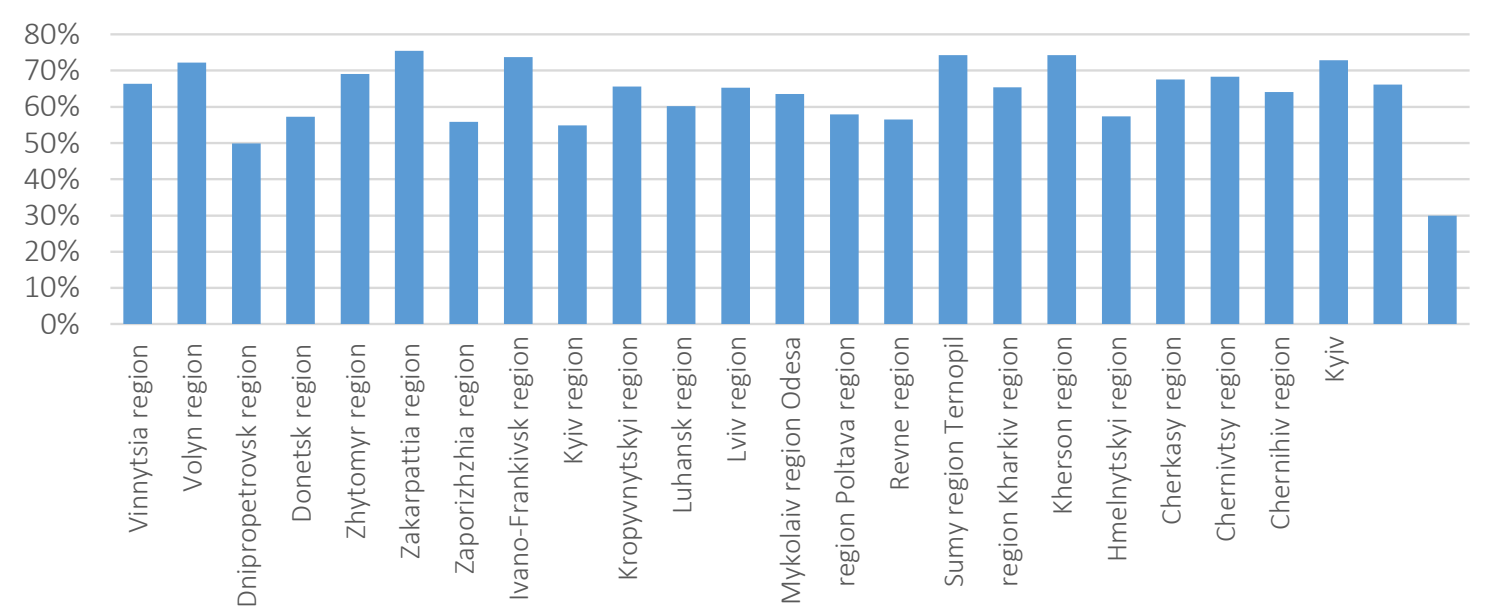

Figure 4. The share of transfers in local budget revenues of Ukraine in 2015 
Source: Compiled according to the data of the State Statistics Service of Ukraine.

\begin{tabular}{|c|c|c|c|c|c|c|c|c|c|c|c|c|c|}
\hline No. & Territory & 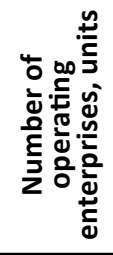 & 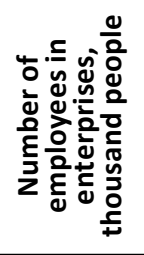 & 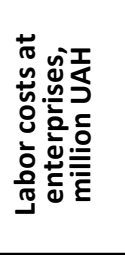 & 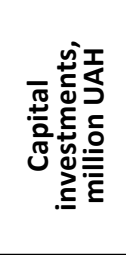 & 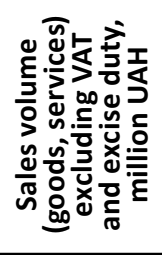 & 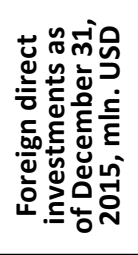 & 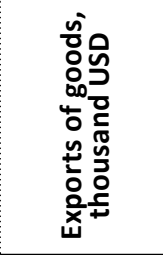 & 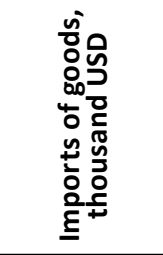 & 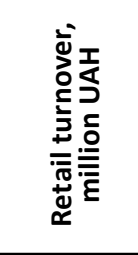 & 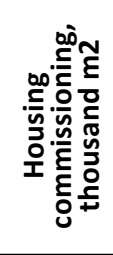 & 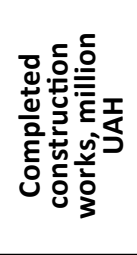 & 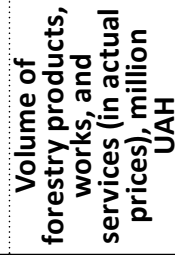 \\
\hline & & $x_{1}$ & $x_{2}$ & $x_{3}$ & $x_{4}$ & $x_{5}$ & $x_{6}$ & $x_{7}$ & $x_{8}$ & $x_{9}$ & $x_{10}$ & $x_{11}$ & $x_{12}$ \\
\hline 1 & Vinnytsia region & 19,940 & 145.8 & $5,679.2$ & $6,989.9$ & $45,161.2$ & 187.1 & $846,856.0$ & $266,668.6$ & $34,345.6$ & 391.4 & $1,537.8$ & 452.3 \\
\hline 2 & Volyn region & 13,680 & 98.5 & $3,762.3$ & $5,527.1$ & $18,447.9$ & 248.1 & $631,693.7$ & $622,087.5$ & $26,502.3$ & 329.1 & $1,089.3$ & 652.1 \\
\hline 3 & Dnipropetrovsk region & 45,072 & 636.6 & $33,343.6$ & $24,330.6$ & $289,142.3$ & $7,182.9$ & 6,398,976.4 & $3,225,259.1$ & $95,160.5$ & 339.8 & $5,745.6$ & 52.4 \\
\hline 4 & Donetsk region & 31,820 & 389.6 & $23,666.1$ & $6,640.7$ & $170,336.9$ & $1,827.7$ & $3,695,324.4$ & $1,202,633.4$ & $31,163.5$ & 43.4 & $2,340.2$ & 32.7 \\
\hline 5 & Zhytomyr region & 15,865 & 110.4 & $4,091.6$ & $3,755.0$ & $25,274.5$ & 249.3 & $441,318.7$ & $246,377.7$ & $28,018.4$ & 212.6 & 640.4 & $1,689.2$ \\
\hline 6 & Zakarpattia region & 14,640 & 79.1 & $3,057.7$ & $3,634.8$ & $13,895.0$ & 311.5 & $1,094,379.6$ & $1,011,507.0$ & $24,749.6$ & 442.1 & 620.5 & 549.8 \\
\hline 7 & Zaporizhzhia region & 25,404 & 261.1 & $12,709.0$ & $7,123.3$ & $130,758.4$ & 931.7 & $2,931,027.4$ & $1,085,450.6$ & $47,998.7$ & 101.5 & $1,595.2$ & 33.4 \\
\hline 8 & Ivano-Frankivsk region & 17,255 & 84.5 & $2,932.0$ & $9,285.0$ & $32,674.2$ & 836.6 & $373,000.4$ & $294,496.8$ & $34,093.5$ & 856.2 & $1,324.5$ & 653.2 \\
\hline 9 & Kyiv region & 33,087 & 326.9 & $16,932.4$ & $22,936.1$ & $68,651.1$ & $1,627.1$ & $1,690,436.6$ & $2,587,043.9$ & $52,123.5$ & $1,863.8$ & $2,875.3$ & 895.6 \\
\hline 10 & Kropyvnytskyi region & 14,246 & 92.8 & $3,126.3$ & $3,800.4$ & $20,319.3$ & 64.4 & $406,551.9$ & $105,420.5$ & $21,653.4$ & 117.1 & 674.4 & 121.7 \\
\hline 11 & Luhansk region & 13,891 & 105.9 & $4,882.0$ & $1,826.5$ & $24,866.7$ & 582.4 & $257,771.8$ & $318,426.2$ & $7,871.3$ & 22.2 & 544.4 & 66.4 \\
\hline 12 & Lviv region & 35,905 & 328.5 & $14,024.2$ & $11,845.4$ & $53,955.5$ & $1,248.1$ & $1,206,324.8$ & $1,447,944.9$ & $56,720.5$ & $1,164.7$ & $3,669.2$ & 788.5 \\
\hline 13 & Mykolaiv region & 19,451 & 118.2 & $5,305.7$ & $5,761.5$ & $34,357.7$ & 212.7 & $1,603,063.6$ & $574,741.1$ & $28,595.1$ & 168.3 & $1,558.7$ & 37.0 \\
\hline 14 & Odesa region & 38,661 & 308.3 & $13,869.4$ & $8,408.7$ & $44,437.7$ & $1,337.4$ & $1,727,480.4$ & $967,276.0$ & $72,438.9$ & 631.8 & $4,554.5$ & 83.1 \\
\hline 15 & Poltava region & 20,600 & 211.1 & $9,250.0$ & $7,606.1$ & $103,303.3$ & $1,000.6$ & $1,481,082.0$ & $814,488.8$ & $29,747.1$ & 266.3 & $4,249.3$ & 245.5 \\
\hline 16 & Rivne region & 13,188 & 84.2 & $3,116.4$ & $4,176.9$ & $26,115.3$ & 220.2 & $378,286.5$ & $202,338.5$ & $23,853.6$ & 360.6 & $1,332.0$ & $1,077.4$ \\
\hline 17 & Sumy region & 13,075 & 111.5 & $4,696.0$ & $3,508.8$ & $32,445.5$ & 201.6 & $606,604.7$ & $403,547.9$ & $22,551.0$ & 157.1 & 881.2 & 657.7 \\
\hline 18 & Ternopil region & 13,639 & 73.2 & $2,562.0$ & $3,536.5$ & $11,826.9$ & 50.1 & $290,982.8$ & $259,432.7$ & $20,284.7$ & 479.7 & 946.6 & 182.2 \\
\hline 19 & Kharkiv region & 39,078 & 386.6 & $15,718.2$ & $10,520.5$ & $102,115.5$ & $1,569.5$ & $1,311,586.9$ & $1,284,945.9$ & $83,475.6$ & 383.6 & $5,054.5$ & 188.9 \\
\hline 20 & Kherson region & 15,511 & 80.9 & $2,588.8$ & $2,926.5$ & $20,323.8$ & 210.6 & $238,440.0$ & $140,901.5$ & $26,497.3$ & 112.9 & 532.7 & 56.6 \\
\hline 21 & Hmelnytskyi region & 17,188 & 106.5 & $3,816.3$ & $6,523.9$ & $26,358.3$ & 166.8 & $401,620.9$ & $259,270.4$ & $25,693.0$ & 468.7 & $1,336.2$ & 470.2 \\
\hline 22 & Cherkasy region & 17,630 & 129.0 & $4,874.1$ & $4,196.2$ & $44,249.7$ & 352.9 & $434,189.9$ & $228,094.4$ & $27,778.5$ & 192.8 & 825.0 & 477.2 \\
\hline 23 & Chernivtsi region & 10,191 & 48.9 & $1,542.3$ & $2,607.8$ & $6,742.4$ & 59.3 & $108,294.5$ & $78,384.1$ & $17,324.4$ & 382.4 & 941.3 & 417.0 \\
\hline 24 & Chernihiv region & 13,428 & 97.9 & $3,671.4$ & $3,469.3$ & $20,513.7$ & 92.2 & $551,601.7$ & $379,972.4$ & $21,614.9$ & 190.5 & 573.0 & 762.4 \\
\hline 25 & Kyiv & 112,324 & $1,616.8$ & $90,125.3$ & $80,216.8$ & $124,306.7$ & $22,600.4$ & $8,742,884.2$ & $14,495,410.9$ & $158,523.3$ & $1,365.8$ & $12,073.2$ & 135.7 \\
\hline
\end{tabular}


Using the method of major components, we will find out what indicators of regional economic development affect local budget revenues. The preliminary analysis made it possible to identify 12 indicators of economic development of Ukrainian regions in 2015 , which are respectively designated as independent variables $x_{1}-x_{12}$. (Table 2), and indicators of local budget revenues (excluding inter-budgetary transfers) in 2015 - the dependent variable $y_{1}$ (Table 3 ).

Table 3. Revenues of local budgets in Ukraine in 2015

Source: Compiled according to the data of the State Treasury Service of Ukraine.

\begin{tabular}{|c|c|c|}
\hline No. & Territory & $\begin{array}{c}\text { Locally collected revenues } \\
\text { (excluding transfers), } \\
\text { UAH million }\end{array}$ \\
\hline 1 & Vinnytsia region & $3,790.52$ \\
\hline 2 & Volyn region & $2,208.94$ \\
\hline 3 & $\begin{array}{l}\text { Dnipropetrovsk } \\
\text { region }\end{array}$ & $13,203.38$ \\
\hline 4 & Donetsk region & $7,092.88$ \\
\hline 5 & Zhytomyr region & $2,765.17$ \\
\hline 6 & Zakarpattia region & $2,071.09$ \\
\hline 7 & Zaporizhzhia region & $5,602.21$ \\
\hline 8 & $\begin{array}{l}\text { Ivano-Frankivsk } \\
\text { region }\end{array}$ & $2,571.23$ \\
\hline 9 & Kyiv region & $6,141.99$ \\
\hline 10 & Kropyvnytskyi region & $2,419.05$ \\
\hline 11 & Luhansk region & $2,163.56$ \\
\hline 12 & Lviv region & $6,411.99$ \\
\hline 13 & Mykolaiv region & $2,942.97$ \\
\hline 14 & Odesa region & $6,939.80$ \\
\hline 15 & Poltava region & $4,817.73$ \\
\hline 16 & Rivne region & $2,208.44$ \\
\hline 17 & Sumy region & $2,718.44$ \\
\hline 18 & Ternopil region & $1,860.91$ \\
\hline 19 & Kharkiv region & $7,872.43$ \\
\hline 20 & Kherson region & $2,273.07$ \\
\hline 21 & Hmelnytskyi region & $2,933.67$ \\
\hline 22 & Cherkasy region & $3,193.41$ \\
\hline 23 & Chernivtsi region & $1,656.02$ \\
\hline 24 & Chernihiv region & $2,433.62$ \\
\hline 25 & Kyiv & $22,169.14$ \\
\hline
\end{tabular}

One can assume that there are many cause and effect relationships between the indicators $x_{1}-x_{12}$ and $y_{1}$, which can lead to multicollinearity. To avoid this, it is advisable to replace this set of indicators with a smaller number of uncorrelated indicators (Table 4).

As can be seen from Table 4, our assumption about the existence of relationships between individual indicators that affect budget revenues is confirmed. In particular, there is a strong relationship between all independent variables. Only medium and weak links are traced to the volume of sales (goods, services) excluding VAT and excise duty; housing commissioning; volume of products, works, and services of forestry. The conducted correlation analysis shows that close correlation of indicators of local budget revenues is not traced to all data of economic development. Therefore, we will assume that the impact of economic development indicators on the dependent variable may be partially affected.

The next stage of the study is to reduce the number of independent variables and highlight the main factors that explain the causal mechanisms of the process of local budget revenues. The factor analysis will be carried out by using the method of major components followed by the rotation of the identified load matrix by the method of "varimax". We use the software package "STATISTICA 10 " for multifaceted data analysis. We standardize input data before performing a multifaceted analysis. The condition is that the number of observations ( 25 regions) is two times higher than the number of independent variables (12 indicators). We calculate the values of the correlation matrix based on 12 independent variables (Table 5).

Table 4. Correlation matrix of dependence between indicators

\begin{tabular}{|c|c|c|c|c|c|c|c|c|c|c|c|c|c|}
\hline & $y_{1}$ & $x_{1}$ & $x_{2}$ & $x_{3}$ & $x_{4}$ & $x_{5}$ & $x_{6}$ & $x_{7}$ & $x_{8}$ & $x_{9}$ & $x_{10}$ & $x_{11}$ & $x_{12}$ \\
\hline$y_{1}$ & 1.00 & 0.98 & 0.98 & 0.97 & 0.92 & 0.69 & 0.93 & 0.95 & 0.91 & 0.96 & 0.47 & 0.96 & -0.29 \\
\hline$x_{1}$ & - & 1.00 & 0.99 & 0.98 & 0.95 & 0.53 & 0.95 & 0.89 & 0.95 & 0.96 & 0.55 & 0.96 & -0.26 \\
\hline$x_{2}$ & - & - & 1.00 & 1.00 & 0.97 & 0.58 & 0.97 & 0.92 & 0.97 & 0.93 & 0.49 & 0.95 & -0.26 \\
\hline$x_{3}$ & - & - & - & 1.00 & 0.97 & 0.58 & 0.98 & 0.93 & 0.97 & 0.91 & 0.47 & 0.93 & -0.26 \\
\hline$x_{4}$ & - & - & - & - & 1.00 & 0.44 & 0.98 & 0.86 & 0.99 & 0.89 & 0.61 & 0.90 & -0.15 \\
\hline$x_{5}$ & - & - & - & - & - & 1.00 & 0.48 & 0.79 & 0.41 & 0.60 & 0.06 & 0.58 & -0.37 \\
\hline$x_{6}$ & - & - & - & - & - & - & 1.00 & 0.89 & 0.99 & 0.88 & 0.45 & 0.90 & -0.22 \\
\hline$x_{7}$ & - & - & - & - & - & - & & 1.00 & 0.86 & 0.86 & 0.32 & 0.86 & -0.36 \\
\hline$x_{8}$ & - & - & - & - & - & - & - & - & 1.00 & 0.87 & 0.54 & 0.89 & -0.18 \\
\hline$x_{9}$ & - & - & - & - & - & - & - & - & - & 1.00 & 0.53 & 0.95 & -0.24 \\
\hline$x_{10 .}$ & - & - & - & - & - & - & - & - & - & - & 1.00 & 0.52 & 0.23 \\
\hline$x_{11 .}$ & - & - & - & - & - & - & - & - & - & - & - & 1.00 & -0.28 \\
\hline$x_{12}$ & - & - & - & - & - & - & - & - & - & - & - & - & 1.00 \\
\hline
\end{tabular}


As shown in Table 5, the first two components in the sum explain $88,51 \%$ of the general variance of the original variables indicating a high degree of factorization. The values of these components are bigger than 1, and therefore it is quite fair to attribute the first two components to the main ones.

To visually confirm the correct selection of the main components, we use the scree plot method. Accordingly, in the graph of eigenvalues, starting with the third component, we observe an almost horizontal line parallel to the abscissa. Therefore, the chart (Figure 5) confirms the feasibility of allocating the first two main components.

Table 5. Eigenvalues and the total variance of components

\begin{tabular}{c|c|c}
\hline $\begin{array}{c}\text { Component } \\
\text { number }\end{array}$ & Eigenvalues & $\begin{array}{c}\text { The share of the total } \\
\text { variance, \% }\end{array}$ \\
\hline 1 & 9.15 & 76.25 \\
\hline 2 & 1.47 & 12.27 \\
\hline 3 & 0.61 & 5.11 \\
\hline 4 & 0.47 & 3.90 \\
\hline 5 & 0.18 & 1.54 \\
\hline 6 & 0.05 & 0.39 \\
\hline 7 & 0.03 & 0.27 \\
\hline 9 & 0.02 & 0.17 \\
\hline 10 & 0.01 & 0.05 \\
\hline 11 & 0.00 & 0.03 \\
\hline 12 & 0.00 & 0.01 \\
\hline & 0.00 & 0.00 \\
\hline
\end{tabular}

For their interpretation, we use the factor loadings matrix that characterizes the significance of the influence of each factor (Table 6). Analyzing factor loadings, we conclude that the first component is closely related to the following indicators: the number of operating enterprises; the number of employees in enterprises; labor costs at enterprises; capital investments; foreign direct investments; exports of goods; imports of goods; retail turnover; completed construction works. The second component is closely related to the following indicators: sales volume (goods, services) excluding VAT and excise duty; housing commissioning; volume of forestry products, works, and services.

Table 6. Factor loading on the main components

Source: Compiled and summarized by the authors.

\begin{tabular}{|c|c|c|c|c|}
\hline \multirow{2}{*}{ Indicator } & \multicolumn{2}{|c|}{$\begin{array}{l}\text { Unrotated } \\
\text { loading }\end{array}$} & \multicolumn{2}{|c|}{$\begin{array}{l}\text { Loading after the } \\
\text { rotation by the method } \\
\text { of "varimax" }\end{array}$} \\
\hline & $\begin{array}{c}\text { component } \\
1\end{array}$ & component & $\begin{array}{c}\text { component } \\
1\end{array}$ & ${ }_{2}^{c o m p o n e n t}$ \\
\hline$x_{1}$ & -0.99 & -0.05 & 0.98 & 0.08 \\
\hline$x_{2}$ & -0.99 & -0.00 & 0.99 & 0.13 \\
\hline$x_{3}$ & -0.99 & 0.01 & 0.98 & 0.14 \\
\hline$x_{4}$ & -0.97 & -0.19 & 0.98 & -0.05 \\
\hline$x_{5}$ & -0.61 & 0.54 & 0.53 & 0.62 \\
\hline$x_{6}$ & -0.97 & -0.05 & 0.96 & 0.08 \\
\hline$x_{7}$ & -0.93 & 0.25 & 0.89 & 0.37 \\
\hline$x_{8}$ & -0.96 & -0.14 & 0.97 & -0.02 \\
\hline$x_{9}$ & -0.95 & -0.01 & 0.94 & 0.11 \\
\hline$x_{10}$ & -0.53 & -0.67 & 0.61 & -0.59 \\
\hline$x_{11}$ & -0.96 & 0.01 & 0.95 & 0.13 \\
\hline$x_{12}$ & 0.27 & -0.78 & -0.17 & -0.81 \\
\hline $\begin{array}{l}\text { Share of } \\
\text { the total } \\
\text { variance, } \\
\%\end{array}$ & 0.76 & 0.12 & 0.75 & 0.13 \\
\hline
\end{tabular}

Source: Compiled and summarized by the authors.

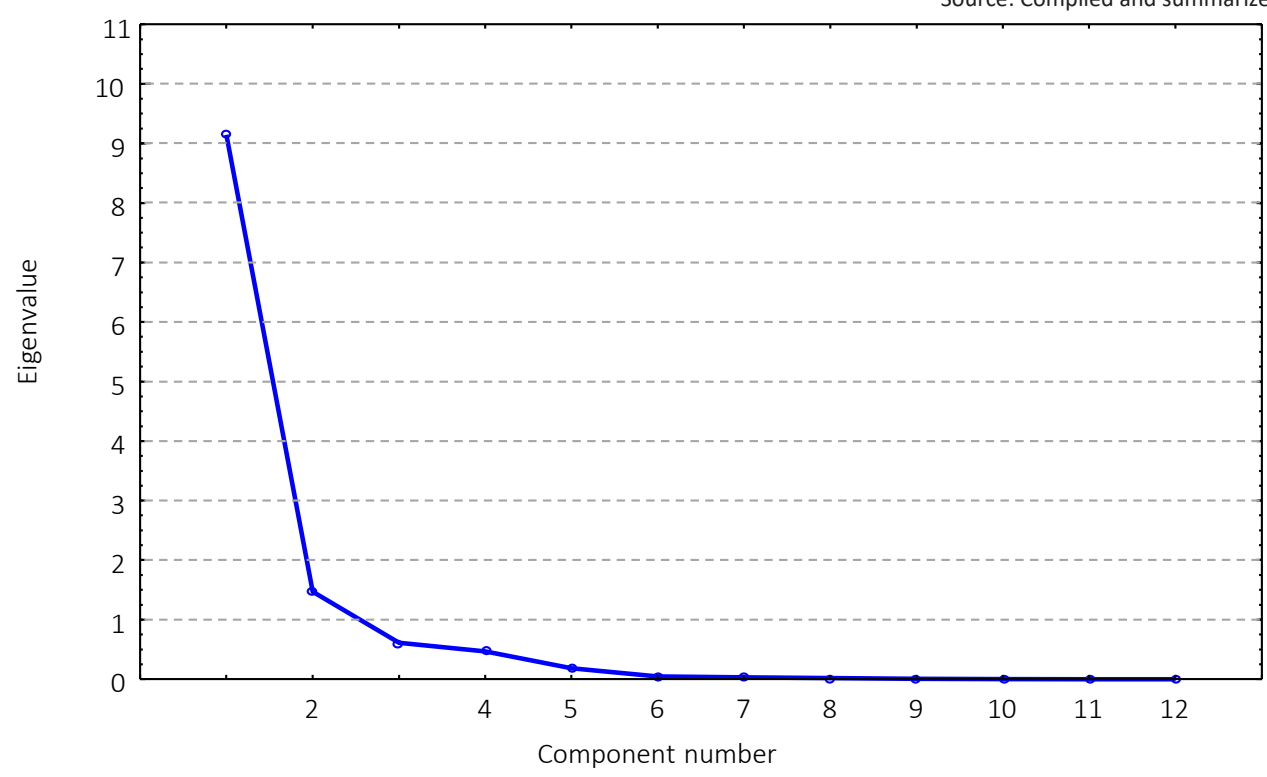

Figure 5. Graph of eigenvalues of components according to the scree plot method 
The results of the empirical study showed that both main components affect local budget revenues. At the same time, the amount of local budget revenues depends to a greater extent (75\%) on the indicators of the first component, while the indicators of the second component have a small (13\%) impact on it.

The use of the major component method made it possible to systematize the factors that determine the volume of local budget revenues and to conduct a regression analysis at the next stage of the study to assess the degree of influence of each factor on the resultant indicator.

To build a regression model one factor was selected from each component that influences the financial capacity of the region. Thus, indicator $x_{1}$ - the number of operating enterprises - was taken from the first component, whereas indicator $x_{5}$ - the volume of sales (goods, services) excluding VAT and excise - was taken from the second component.

The results of the regression analysis conducted with the use of the software package "STATISTICA 10 " are presented in Table 7.

The regression model will look like this:

$$
y=-780.571+0.183 x_{1}+0.017 x_{5},
$$

where $y$ - the volume of local budget revenues; $x_{1}$ the number of operating enterprises in the region; $x_{5}$ - sales volume (goods, services) excluding VAT and excise duty of the region's enterprises.

The values of the coefficient of determination $R^{2}=$ 0.0993 and F-test $(F(2.22)=1,678.3)$ confirm the adequacy of the regression model. The additional coefficients for independent variables indicate that an increase in the value of a particular indicator increases the dependent variable (Table 7).
The presented equation confirms the existence of a close correlation between the volumes of local budget revenues, the number of operating enterprises and sales volumes (goods, services) excluding VAT and excise duty. Therefore, since budgetary decentralization implies the introduction of new instruments of influence of local communities and local self-governments on economic growth of the respective territory, measures should be taken to stimulate entrepreneurial activity, to increase the number of enterprises and promote a continuous flow of goods (works, services) from the producer to the consumer.

To identify the asymmetries of regional development in terms of financial capacity, we will conduct a cluster analysis according to the identified major components. For this purpose, it is necessary to calculate the matrix of factor coefficients for the major components (Table 8).

Table 8. The matrix of factor coefficients of the major components

Source: Compiled and summarized by the authors

\begin{tabular}{c|c|c}
\hline \multirow{2}{*}{ Indicators } & \multicolumn{2}{|c}{ Factor coefficients } \\
\cline { 2 - 3 } & component 1 & component 2 \\
\hline$x_{1}$ & -0.108 & -0.033 \\
\hline$x_{2}$ & -0.109 & -0.002 \\
\hline$x_{3}$ & -0.108 & 0.004 \\
\hline$x_{4}$ & -0.106 & -0.126 \\
\hline$x_{5}$ & -0.066 & 0.369 \\
\hline$x_{6}$ & -0.106 & -0.035 \\
$x_{7}$ & -0.102 & 0.168 \\
$x_{8}$ & -0.105 & -0.098 \\
$x_{9}$ & -0.104 & -0.008 \\
\hline$x_{10}$ & -0.058 & -0.454 \\
$x_{11}$ & -0.105 & 0.004 \\
$x_{12}$ & 0.030 & -0.530 \\
\hline
\end{tabular}

By using the data in Table 8 we will present the equation of relationship of the major components with output parameters:

Table 7. Results of the regression analysis

\begin{tabular}{|c|c|c|c|c|c|c|}
\hline \multicolumn{7}{|c|}{ Regression results for the dependent variable $y R^{2}=0.993 \cdot F(2.22)=1,678.3$} \\
\hline Indicators & Beta & St. err. - of Beta & $\boldsymbol{\beta}$ & $\begin{array}{l}\text { St. err. - of } \\
\text { Beta }\end{array}$ & $t(22)$ & p-level \\
\hline Y-intercept & - & - & -780.571 & 122.9491 & -6.34873 & 0.000002 \\
\hline$x_{1}$ & 0.845182 & 0.020314 & 0.183 & 0.0044 & 41.60493 & 0.000000 \\
\hline$x_{5}$ & 0.244206 & 0.020314 & 0.017 & 0.0014 & 12.02128 & 0.000000 \\
\hline
\end{tabular}


component $1=-0.108 x_{1}-0.109 x_{2}-0.108 x_{3}-$ $-0.106 x_{4}-0.066 x_{5}-0.106 x_{6}-0.102 x_{7}-0.105 x_{8}-$ $-0.104 x_{9}-0.058 x_{10}-0.105 x_{11}+0.03 x_{12}$;

component $2=-0.033 x_{1}-0.002 x_{2}+0.004 x_{3}-$ $-0.126 x_{4}+0.369 x_{5}-0.035 x_{6}+0.168 x_{7}-0.098 x_{8}-$ $-0.008 x_{9}-0.454 x_{10}+0.004 x_{11}-0.53 x_{12}$.

According to the above equations, we calculate the values of the major components for each region of Ukraine (Table 9).

The dendrogram of the results of the cluster analysis is shown in Figure 6. It reflects the sequence of cluster separation. In this case, the similarity of elements is determined by the Euclidean distance, and the method of complete-linkage clustering is used to determine the intervals between clusters.
Based on the visual presentation of the results, it can be assumed that regions form four clusters.

According to Table 9, the K-means method splits the regions into two components into four clusters. The variance analysis confirms the correctness of our assumption about the number of clusters (at the level of significance $p=0.05$, we have differences between the selected groups of regions). By analyzing the average and median values of output indicators for the clusters (Table 10), we can confirm the homogeneity of the regions that fall into one cluster.

The indicators of average values of the major components by clusters (Table 11) make it possible to characterize each cluster by the degree of influence of each element on the volumes of local budget revenues.

Table 9. The values of the major components for the regions of Ukraine

Source: Compiled and summarized by the authors.

\begin{tabular}{|c|c|c|c|c|c|}
\hline Territory & $\begin{array}{c}\text { Value of } \\
\text { component } 1\end{array}$ & $\begin{array}{c}\text { Value of } \\
\text { component } 2\end{array}$ & Territory & $\begin{array}{c}\text { Value of } \\
\text { component } 1\end{array}$ & $\begin{array}{c}\text { Value of } \\
\text { component } 2\end{array}$ \\
\hline Vinnytsia region & 0.3060 & -0.0341 & Odesa region & -0.3056 & 0.1900 \\
\hline Volyn region & 0.4833 & -0.3914 & Poltava region & -0.0077 & 0.7251 \\
\hline Dnipropetrovsk region & -1.6188 & 2.0588 & Rivne region & 0.5455 & -0.9276 \\
\hline Donetsk region & -0.3744 & 1.7680 & Sumy region & 0.5214 & -0.1176 \\
\hline Zhytomyr region & 0.5952 & -1.5769 & Ternopil region & 0.5300 & 0.0312 \\
\hline Zakarpattia region & 0.4730 & -0.3630 & Kharkiv region & -0.4674 & 0.5724 \\
\hline Zaporizhzhia region & -0.1372 & 1.4273 & Kherson region & 0.5467 & 0.6193 \\
\hline Ivano-Frankivsk region & 0.3334 & -0.9053 & Hmelnytskyi region & 0.4295 & -0.2714 \\
\hline Kyiv region & -0.4720 & -2.1628 & Cherkasy region & 0.4455 & 0.1252 \\
\hline Kropyvnytskyi region & 0.5505 & 0.5427 & Chernivtsi region & 0.6325 & -0.1992 \\
\hline Luhansk region & 0.5888 & 0.7349 & Chernihiv region & 0.5756 & -0.3605 \\
\hline Lviv region & -0.2589 & -1.3022 & Kyiv & -4.2279 & -0.9212 \\
\hline Mykolaiv region & 0.3131 & 0.7381 & & & \\
\hline
\end{tabular}

Table 10. Average and median values by clusters

Source: Compiled and summarized by the authors.

\begin{tabular}{|c|c|c|c|c|c|c|c|c|c|c|}
\hline \multirow{2}{*}{ Indicator } & \multicolumn{2}{|c|}{1 cluster } & \multicolumn{2}{|c|}{2 cluster } & \multicolumn{2}{|c|}{3 cluster } & \multicolumn{2}{|c|}{4 cluster } & \multicolumn{2}{|c|}{5 cluster } \\
\hline & average & median & average & median & average & median & average & median & average & median \\
\hline$y$ & 2,519 & 2,321 & 3,803 & 2,742 & 4,204 & 2,943 & 8,633 & 7,093 & 22,169 & 22,169 \\
\hline$x_{1}$ & 15,042 & 14,160 & 21,396 & 16,560 & 23,063 & 19,451 & 34,099 & 31,820 & 112,324 & 112,324 \\
\hline$x_{2}$ & 97 & 98 & 174 & 111 & 186 & 118 & 429 & 390 & 1,617 & 1,617 \\
\hline$x_{3}$ & 3,621 & 3,717 & 7,632 & 4,394 & 7,820 & 5,306 & 23,240 & 23,666 & 90,125 & 90,125 \\
\hline$x_{4}$ & 4,561 & 3,916 & 9,251 & 6,731 & 5,836 & 5,762 & 12,698 & 7,123 & 80,217 & 80,217 \\
\hline$x_{5}$ & 23,399 & 19,481 & 39,853 & 32,560 & 49,961 & 34,358 & 196,746 & 170,337 & 124,307 & 124,307 \\
\hline$x_{6}$ & 184 & 177 & 730 & 543 & 711 & 582 & 3,314 & 1,828 & 22,600 & 22,600 \\
\hline$x_{7}$ & 544,952 & 492,896 & 782,662 & 523,962 & $1,003,711$ & $1,311,587$ & $4,341,776$ & $3,695,324$ & $8,742,884$ & $8,742,884$ \\
\hline$x_{8}$ & 388,177 & 263,051 & 863,625 & 349,022 & 600,886 & 574,741 & $1,837,781$ & $1,202,633$ & $14,495,411$ & $1,449,5411$ \\
\hline$x_{9}$ & 24,787 & 25,221 & 36,227 & 31,056 & 38,611 & 28,595 & 58,108 & 47,999 & 158,523 & 158,523 \\
\hline$x_{10}$ & 360 & 387 & 769 & 608 & 243 & 168 & 162 & 102 & 1,366 & 1,366 \\
\hline$x_{11}$ & 984 & 944 & 1,787 & 1,328 & 2,453 & 1,559 & 3,227 & 2,340 & 12,073 & 12,073 \\
\hline$x_{12}$ & 495 & 474 & 960 & 842 & 114 & 83 & 40 & 33 & 136 & 136 \\
\hline
\end{tabular}




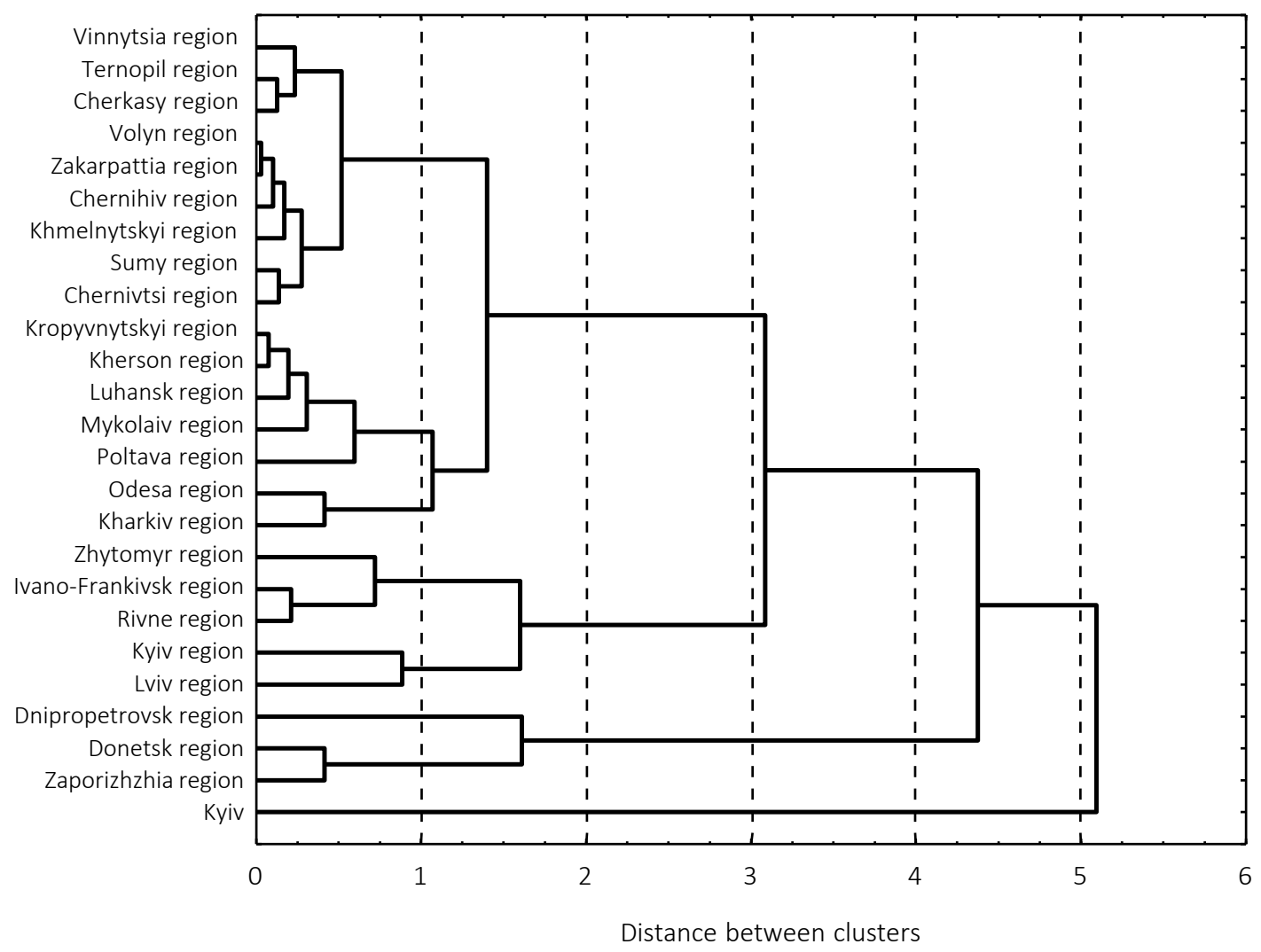

Figure 6. Dendrogram of the results of clustering of Ukraine's regions

The first cluster included the regions where there were negative tendencies of economic development: Vinnytsia, Volyn, Zakarpattia, Sumy, Ternopil, Khmelnytskyi, Cherkasy, Chernivtsi, Chernihiv regions. This cluster is formed by regions whose industrial capacity is shaped by agrarian, light, and food industries. Therefore, stimulation of the development of these areas will have a positive impact on increasing the financial independence of local budgets.

The second cluster combined regions with average indicators of economic development: Zhytomyr, Ivano-Frankivsk, Kyiv, Lviv and Rivne regions. The economic capacity of these regions is shaped by metal-processing, oil and gas, light industries and electrical energy industry. Accordingly, the growth of local budget revenues depends on the stimulation of entrepreneurial activity in these areas.

The third cluster includes those regions that have good preconditions for economic development: Kropyvnytskyi, Luhansk, Mykolaiv, Odesa, Poltava, Kharkiv, Kherson regions. The leading industry of the Kirovohrad region is agricultural production.

Machine building, coal, metallurgy, and chemical industries are well developed in the Luhansk region, but in 2014-2015, there was a decrease in industrial production, exports and imports of goods, which negatively affected the overall economic

Table 11. Average values of the major components by clusters

\begin{tabular}{l|ccc}
\hline \multirow{2}{*}{ Clusters } & & Main components & component 2 \\
\cline { 2 - 4 } & component 1 & -0.17 \\
\hline Cluster 1 & 0.46 & 0.14 & -1.37 \\
Cluster 2 & 0.17 & -0.62 & 0.58 \\
Cluster 3 & & 1.75 \\
\hline Cluster 4 & & & \\
\hline
\end{tabular}


development trends in the region. The Mykolaiv region is known for its multi-sectoral industry and the prospects of infrastructure development. The Odesa region is one of the most promising regarding the development of foreign economic activity and joint ventures. The Poltava region has large export opportunities, which can be realized if additional investment resources are attracted. The Kharkiv region is one of the most attractive in terms of investments. The Kherson region is one of the most developed agro-industrial regions.

The fourth cluster is formed by economically developed regions: Dnipropetrovsk, Donetsk, and Zaporizhzhia regions. The Dnipropetrovsk region is a leader in terms of sales, reconstruction of infrastructure facilities, attraction of investments; the majority of metallurgical enterprises are located in the Donetsk region, but the decline in industrial production in 2014-2015 had a negative im- pact on its economic development; Zaporizhzhia region is the center of domestic aviation industry and one of the largest producers of agricultural products. This has a positive effect on the revenues of the relevant local budgets, which makes it possible to outline the vectors for improving the quality of life of people living in these territories.

Kyiv is the fifth cluster, which, as the state's capital, financial and trade center, occupies a special place in the rating of regions and, for objective reasons, has the highest economic indicators, including the number of operating enterprises, the number of employees employed in the enterprises, labor costs, capital investments, foreign direct investments, exports of goods, imports of goods, retail turnover and completed construction works. This creates the conditions for the formation of financial independence of the local budget and the support of quality public services to the population.

\section{CONCLUSION}

Budget decentralization is closely correlated with economic capabilities of the regions. Based on the conducted research, the authors have proposed a system of indicators that allows to consider the peculiarities of the regional economy development and have a direct impact on local budget revenues (without inter-budgetary transfers).

The method of major components and the factor loading matrix allowed to identify two main components: the first component is closely related to the following indicators: number of operating enterprises; number of employees; labor costs; capital investments; foreign direct investments; exports of goods; imports of goods; retail turnover; completed construction works. The second component is closely related to such indicators as sales volume (goods, services) excluding VAT and excise duty; housing commissioning; volume of forestry products, works, and services.

The results of the empirical study show that abovementioned components affect local budget revenues. At the same time, the volume of local budget revenues depends to a greater extent $(75 \%)$ on the indicators of the first component, whereas the indicators of the second component have a small (13\%) impact on it.

As budgetary decentralization implies the introduction of new instruments of influence of local communities and local self-governments on the economic growth of the respective territory, proper measures should be taken to stimulate entrepreneurial activity, to increase the number of enterprises and to promote a continuous flow of goods (works, services) from the producer to the consumer.

According to results of scientific research, the asymmetry of regional development in terms of financial capacity is determined based on the cluster analysis using the matrix of factor coefficients of the major components and their mean values by clusters. This approach allowed to divide the regions of Ukraine into five clusters according to the level of economic development of their territories. Therefore, the indicators of mean values of the major components by clusters made it possible to characterize each cluster according to the degree of influence of each component on the volumes of local budget revenues. 
One of goals of the budgetary regulation system is to ensure economic growth of regions. The main basis for fiscal decentralization is the development of resource base of local authorities. At the same time, stimulation of economic development of territories (attracting investments, supporting entrepreneurs, supporting start-ups, developing specific industries) will increase the revenues of local budgets and, as a result, improve the quality of public goods and services to population.

\section{ACKNOWLEDGMENT}

The research is performed within the framework of the scientific project "Development of scientific and methodological bases and practical tools of the financial policy of sustainable development of the united territorial communities".

\section{REFERENCES}

1. Affleck, A., \& Mellor, M. (2006). Community development finance: a neo-market solution to financial exclusion? Journal of Social Policy, 35(2), 303-331. https://doi. org/10.1017/S0047279405009542

2. Andrushchenko, V. L. (2013). Міжбюджетні відносини в Україні і міжнародний досвід. [Mizhbiudzhetni vidnosyny v Ukraini i mizhnarodnyi dosvid]. Zbirnyk naukovykh prats Irpinskoi finansovo-yurydychnoi akademii, 2, 7-8.

3. Arikan, G. (2004). Fiscal decentralization: A remedy for corruption? International Tax and Public Finance, 11, 175195. https://doi.org/10.1023/ B:ITAX.0000011399.00053.a1

4. Barro, R. J. (1990). Government Spending in a Simple Model of Endogenous Gruwth. The Journal of Political Economy, 98(5), 2. Retrieved from https://www.nber. org/papers/w2588

5. Blankart, Sh. (2000). Державні фінанси в умовах демократіі [Derzhavni finansy v umovakh demokratii] (653 p.). Kyiv: Lybid.

6. Chygryn, O., Petrushenko, Y., Vysochyna, A., \& Vorontsova, A. (2018). Assessment of Fiscal Decentralization Influence on Social and Economic Development. Montenegrin Journal of Economics, 14(4), 69-84. http://doi.org/10.14254/18005845/2018.14-4.5
7. Faguet, J.-P. (1997).

Decentralization and Local Government Performance (Technical Consultation on Decentralization). London School of Economics. Retrieved from http://www.fao.org/3/ad697e/ ad697e00.htm

8. Fisman, R., \& Gatti, R. (2002). Decentralization and corruption: Evidence across countries. Journal of Public Economics, 83, 325-345. https://doi.org/10.1016/S00472727(00)00158-4

9. Gibson, J., Ivancevich, J., \& Donelly, J. (1991). Organization: Behaviour, Structure, Processes (507 p.). Homewood: Irwin.

10. Kendal, J. (2012). Local financial development and growth. Journal of Banking \& Finance, 36, 15481562. https://doi.org/10.1016/j. jbankfin.2012.01.001

11. Kozarezenko, L., Petrushenko, Y., \& Tulai, O. (2018). Innovation in Public Finance Management of Sustainable Human Development. Marketing and Management of Innovations, 4, 191-202. http://doi. org/10.21272/mmi.2018.4-17

12. Kuzkin, Y. (2018). Estimation of structural and regional differentiation of municipal budgets under financial decentralization (case for Ukraine). Public and Municipal Finance, 7, 29-40. http://dx.doi. org/10.21511/pmf.06(4).2017.04
13. Lunina, I. O. (2014). Бюджетна децентралізація: цілі та напрями реформ [Biudzhetna detsentralizatsiia: tsili ta napriamy reform]. Ekonomika Ukrainy, 11, 62.

14. Musgrave, R. A. (1957). A multiple Theory of Budget Determination. Finanszarchiv, 17(3), 333-343. Retrieved from https://www.jstor.org/stable/40909134

15. Musgrave, R. A., \& Musgrave, P. B. (1989). Public Finanse in Theory and Practice (627 p.). NY: McGraw Hill.

16. Oates, W. (1972). Fiscal Federalism (256 p.). NY: Harcourt Brace Jovanovich.

17. Oates, W. (1994). Federalism and Government Finance. In J. M. Quigley \& E. Smolensky (Eds.), Modern Public Finance. Harvard University Press, Cambridge, Massachusetts, and London, England.

18. Pasichnyi, M. (2017). Empirical study of the fiscal policy impact on economic growth. Problems and Perspectives in Management, 15(3), 316-322. http://dx.doi. org/10.21511/ppm.15(32).2017.01

19. Petrushenko, Y., Kostyuchenko, N., Smolennikov, D., \& Vorontsova, A. (2017). Impact of the participatory financing of international development projects on social capital of the local communities. 
Problems and Perspectives in Management, 15(3), 183-192. http://dx.doi.org/10.21511/ ppm.15(3-1).2017.02

20. Tiebout, C. A. (1956). Pure Theory of Local Expenditures. The Journal of Political Economy, 64(5), 416424. Retrieved from https://www. jstor.org/stable/1826343

21. Tulai, O. (2016). Державні фінанси і сталий людський розвиток: концептуальні домінанти та діалектична $\epsilon \partial$ нicms [Derzhavni finansy i stalyi liudskyi rozvytok: kontseptualni dominanty ta dialektychna yednist] (416 p.). Ternopil: TNEU.

22. Vedel, J. (1973).

Административное право Франиии [Administrativnoe pravo Frantsii] (512 p.). Moscow: Progress.

23. World Bank. (2002). Separation of powers between the individual levels of government of Central Asian countries: prospects for further development (The Fiscal Decentralization Initiative for Central and Eastern Europe).

24. World Bank. (2005). The Effectiveness of World Bank Support for Community-Based and-Driven Development. An OED Evaluation. Washington: The World Bank. Retrieved from http://documents.worldbank.org/ curated/en/660951468152956553/ pdf/347730Effectiv101OFFICIAL0 USE0ONLY1.pdf 